FOUNDATIONS OF CONTINUUM THERMODYNAMICS 


\section{FOUNDATIONS OF CONTINUUM THERMODYNAMICS}

Edited by

J. J. DELGADO DOMINGOS, M. N. R. NINA AND

J. H. WHITELAW 
ISBN 978-1-349-02237-3 ISBN 978-1-349-02235-9 (eBook)

DOI 10.1007/978-1-349-02235-9

(C) Instituto de Alta Cultura-Núcleo de

Estudos de Engenharia Mecanica 1973

Softcover reprint of the hardcover 1st edition 1973 978-0-333-16642-0

All rights reserved. No part of this publication, may be reproduced or transmitted, in any form or by any means, without prior permission.

\author{
First published 1974 by \\ THE MACMILLAN PRESS LTD. \\ London and Basingstoke \\ Associated companies in New York \\ Melbourne Dublin Johannesburg and Madras
}

SBN 333166426 


\author{
Proceedings \\ of an \\ International Symposium \\ held at \\ BUSSACO, PORTUGAL
}

Sponsored by the Portuguese

Ministry of Education

Honorary President:

Scientific Committee:

Executive Secretary:

Scientific Editors:
J. VEIGA SIMÃO, LISBON

J. J. DELGADO DOMINGOS, LISBON

P. GERMAIN, PARIS

J. KESTIN, PROVIDENCE, R.I.

J. MEIXNER, AACHEN

R. S. RIVLIN, BETHLEHEM, Pa.

M. N. R. NINA, LISBON

J. J. DELGADO DOMINGOS, LISBON

M. N. R. NINA, LISBON

J. H. WHITELAW, LONDON 


\section{Preface}

The contributions contained in this volume were presented at an International Symposium on the Foundations of Continuum Thermodynamics held at Bussaco, Portugal, from 22 to 26 July 1973 . The symposium had its origin in informal discussions between Professors Domingos and Kestin early in 1971; these discussions led to the formation of the Organisation Committee which formulated the following purposes for the symposium:

to arrange a thorough exchange of views on the Foundations of Continuum Thermodynamics between a small number of the most active contributors to this field, and so to make it possible for representatives of different approaches to understand the other's point of view.

to attempt to work out a commonly agreed point of view on the physical foundations of the subject.

to make the results of these deliberations available to the scientific community at large.

This volume of proceedings is intended to fulfill the last of these purposes.

The symposium programme is closely reflected in these proceedings. Sixteen papers were presented and, of these, five were designed specifically to comment and expand upon a topic discussed in a previous paper. A seventeenth lecture was presented by P. Germain and had the purpose of reviewing the achievements of the symposium. This lecture was subsequently written as a paper and is included here; it represents an up-to-date review of the state of the art. The programme included eleven open forum sessions which allowed lively and extensive discussions: a selection of the more important comments is included in these proceedings in the form of dialogue presented in discussion sections which follow the relevant lectures.

We hope that these proceedings will assist teachers and researchers in thermodynamics and related subjects to appreciate the current views of the leading workers in continuum thermodynamics and to learn from their efforts. This volume cannot completely communicate the stimulating atmosphere of the symposium but we hope that the discussion sections, particularly, will provide an indication.

JJDD

MNRN

JHW 


\section{Participants}

\begin{tabular}{|c|c|}
\hline BORGES, A. J. & Universidade de Coimbra, Portugal \\
\hline BROTAS, A. & Instituto Superior Técnico, Lisboa, Portugal \\
\hline CALLEN, Herbert B. & University of Pennsylvania, USA \\
\hline CHAVES, M. R. & Universidade do Porto, Portugal \\
\hline COSTA, J. A. M. P. & Instituto Superior Técnico, Lisboa, Portugal \\
\hline COSTA, J. Providência e & Universidade de Coimbra, Portugal \\
\hline DOMINGOS, J. J. D. & Instituto Superior Técnico, Lisboa, Portugal \\
\hline FALCÃO, A. F. O. & Instituto Superior Técnico, Lisboa, Portugal \\
\hline FILIPE, M. A. & Faculdade de Ciências de Lisboa, Portugal \\
\hline GERMAIN, Paul & Université de Paris, France \\
\hline GLANSDORFF, Paul & Université Libre de Bruxelles, Belgium \\
\hline DE GROOT, S. R. & $\begin{array}{l}\text { Instituut voor Theoretische Fysica, Amsterdam, } \\
\text { Netherlands }\end{array}$ \\
\hline KESTIN, Joseph & Brown University, USA \\
\hline LARANJEIRA, M. F. & Universidade de Luanda, Angola \\
\hline LEAL, A. B. & Universidade de Luanda, Angola \\
\hline LEE, Erastus $\mathrm{H}$. & Stanford University, USA \\
\hline LEMOS, A. M. F. T. & Instituto Superior Técnico, Lisboa, Portugal \\
\hline MANDEL, J. & Ecole Polytechnique de Paris, France \\
\hline MASON, E. A. & Brown University, USA \\
\hline MEIXNER, Joseph & $\begin{array}{l}\text { Institut für Theoretische Physik, Aachen, } \\
\text { West Germany }\end{array}$ \\
\hline MILLER, Donald G. & University of California, USA \\
\hline MÜLLER, Ingo & The Johns Hopkins University, USA \\
\hline NASSER, S. Nemat- & Northwestern University, USA \\
\hline NINA, M. N. R. & Instituto Superior Técnico, Lisboa, Portugal \\
\hline PINA, H. L. G. & Instituto Superior Técnico, Lisboa, Portugal \\
\hline PINHEIRO, M. F. & Universidade do Porto, Portugal \\
\hline PORTELA, A. G. & Instituto Superior Técnico, Lisboa, Portugal \\
\hline PRIGOGINE, I. & Université Libre de Bruxelles, Belgium \\
\hline REIS, M. & Université Libre de Bruxelles, Belgium \\
\hline RIVLIN, Ronald s. & Lehigh University, USA \\
\hline SCHLÖGL, F. & $\begin{array}{l}\text { Institut für Theoretische Physik, Aachen, } \\
\text { West Germany }\end{array}$ \\
\hline SIDOROFF, F. & Université de Paris, France \\
\hline SILVA, J. Machado da & Universidade do Porto, Portugal \\
\hline SILVA, J. Ferreira da & Universidade do Porto, Portugal \\
\hline SILVA, J. F. Azevedo e & Faculdade de Ciências de Lisboa, Portugal \\
\hline SOUSA, A. C. Mendes de & $\begin{array}{l}\text { Universidade de Lourenco Marques, Mozam } \\
\text { ix }\end{array}$ \\
\hline
\end{tabular}


SOUSA, J. A. B. Menezes

TELLES, A. silva

TISZA, Laszlo

VENTURA, M. T.

WHITELAW, J. H.
Universidade do Porto, Portugal

Universidade Federal do Rio de Janeiro, Brazil

Massachusetts Institute of Technology, USA

Laboratório Nacional de Engenharia Civil, Lisboa, Portugal

Imperial College, United Kingdom 


\section{Contents}

Preface

vii

List of Participants

1. J. J. Delgado Domingos

From thermostatics to

ix

thermodynamics

2. I. Müller

From thermostatics to thermo-

dynamics; discussion paper

3. L. Tisza

Discussion

Statistical thermodynamics of

equilibrium: STE

Discussion

58

4. H. B. Callen

A symmetry interpretation of

thermodynamics

Discussion 79

5. I. Prigogine

Microscopic aspects of entropy and the statistical foundations of nonequilibrium thermodynamics

Discussion

6. F. Schlögl

Statistical inequalities and

thermodynamics of open systems

7. J. Meixner

Entropy and entropy production

8. J. Kestin

Entropy and entropy production;

discussion paper

Discussion

9. S. R. de Groot

The Onsager relations; theoretical basis

Discussion

10. D. G. Miller

The Onsager relations; experi-

mental evidence

11. E. A. Mason

The Onsager reciprocal relations

-experimental evidence; discussion paper

Discussion

12. R. S. Rivlin

Some restrictions on constitutive

equations

13. E. H. Lee

Some restrictions on constitutive

equations; discussion paper

Discussion 
14. S. Nemat-Nasser

15. J. Mandel

16. H. Pina

17. P. Germain

Index
On nonequilibrium thermo-

dynamics of viscoelasticity and viscoplasticity

Thermodynamics and plasticity 283

Thermodynamics and plasticity; 305

discussion paper

Discussion

312

The role of thermodynamics in

317

continuum mechanics 